\title{
Improved Shoot Organogenesis from Leaves of Grape
}

\author{
James A. Stamp', Sheila M. Colby, and Carole P. Meredith ${ }^{2}$ \\ Department of Viticulture and Enology, University of California, Davis, CA 95616 \\ Additional index words. Vitis vinifera, plant tissue culture, adventitious shoot, regeneration
}

\begin{abstract}
Adventitious shoots developed within 3 weeks from the petiolar stub and, less often, from wounded lamina tissues when leaves excised from nodal cultures of Vitis vinifera L. Cvs. French Colombard and Thompson Seedless were cultured on solid Nitsch and Nitsch medium containing BAP at $2 \mathrm{mg} \cdot \mathrm{liter}^{-1}$. The youngest leaf that could be excised, from 1 to $8 \mathrm{~mm}$ long, was the most responsive $(90 \%$ of explants producing shoots compared to $16 \%$ for leaf 6). Removal of the lamina from the petiolar stub within the first 3 weeks of culture reduced shoot production. Increase in nodal culture age, without transfer to fresh medium, had no effect on subsequent regeneration from the youngest leaves but did reduce the regeneration frequency of leaves at the next position from $43 \%$ to $20 \%$. In regularly subculture nodal cultures, the number of transfers had no effect on subsequent regeneration. Leaves from recently established shoot tip cultures were more responsive than leaves from nodal cultures. The frequency of shoot production was higher in laterally bisected than intact leaves (70\% vs. $43 \%)$ due to additional regeneration from the distal leaf half at the sites of severed veins. Shoot outgrowth was promoted by the isolation and subculture of regenerating tissue to fresh regeneration medium. Petiolar stub removal promoted de novo shoot organogenesis from the resulting lamina wound. Shoots rooted at a high frequency on Murashige and Skoog medium with $1 \mathrm{mg}$ IA-A/liter and produced morphologically normal plants. Chemical names used: 6-benzylaminopurine (BAP); indole-3-acetic acid (IAA).
\end{abstract}

The use of gene transfer for plant improvement depends on the development of appropriate techniques for the introduction of genes into the plant genome. Common to most methods of gene transfer is the requirement for tissue culture systems that permit the regeneration of whole plants from transgenic tissues. With Agrobacterium-medjated gene transfer in particular, it is critical that regeneration occur at a wound site and at high frequency.

In grape, adventitious plant regeneration can be achieved from several explant types by both shoot organogenesis (Barlass and Skene, 1978, 1980a; Favre, 1977; Rajasekaran and Mullins, 1981; Stamp et al., 1990) and somatic embryogenesis (Bouquet et al., 1982; Gray and Mortensen, 1987; Hirabayashi, 1985; Krul and Worley, 1977; Mauro et al., 1986; Mullins and Srinivasan, 1976; Rajasekaran and Mullins, 1979, 1983; Srinivasan and Mullins, 1980; Stamp and Meredith, 1988a, 1988b). The methods described have been used with various genotypes, ranging from wild species to economically important wine, table, raisin, and rootstock cultivars (Monette, 1988). To develop an efficient regeneration system that is compatible with gene transfer and applicable to many genotypes, we previously investigated direct shoot organogenesis from the petiolar stub and lamina of young leaves isolated from nodal cultures of seven grape cultivars (Stamp et al., 1990). The objective of the studies reported here was to identify explant and cultural manipulations that would improve shoot organogenesis from leaves of the important Vitis vinifera cultivars French Colombard and Thompson Seedless, which together account for almost half of the grape area in California (California Agricultural Statistics Serv., 1989).

Received for publication 8 Aug. 1989. Supported by the American Vineyard Foundation, the California Raisin Advisory Board, and the California Table Grape Commission. The technical assistance of Theresa R. Castor is gratefully acknowledged. The cost of publishing this paper was defrayed in part by the payment of page charges. Under postal regulations, this paper therefore must be hereby marked advertisement solely to indicate this fact.

'Present address: Agritope Inc., 15425 S.W. Koll Parkway, Beaverton, OR 97006 .

${ }^{2}$ To whom reprint requests should be addressed.
Materials and Methods

\section{Media preparation and incubation conditions}

All culture media contained $20 \mathrm{~g}$ sucrose and $7 \mathrm{~g}$ Difco Bactoagar/liter. Media were adjusted to $\mathrm{pH} 5.7$, autoclave at 103 $\mathrm{kPa}$ for 24 rein, and dispensed at $20 \mathrm{ml}$ per $100 \times 15-\mathrm{mm}$ plastic petri dish. IAA was filter-sterilized $(0.2-\mu \mathrm{m}$ pore) and added after autoclaving. Cultures were incubated at $25 \pm 1 \mathrm{C}$ with a 16-hr photoperiod $\left(40 \mu \mathrm{mol} \cdot \mathrm{s}^{-1} \cdot \mathrm{m}^{-2}\right.$, cool-white fluorescent lamps). Five shoot tips, five two-node stem segments, or seven leaves (abaxial surface down) were cultured in each petri dish.

\section{Nodal cultures}

Greenhouse-grown shoots of 'French Colombard' (syn. 'Colombard') and 'Thompson Seedless' (syn. 'Sultana') were produced from dormant cuttings planted in sand (Stamp and Meredith, 1988a). Six-week-old nonwoody shoots were cut into one-node segments and surface-sterilized for $5 \mathrm{~min}$ in a solution containing $1.3 \%$ sodium hypochlorite $(25 \% \mathrm{v} / \mathrm{v}$ commercial bleach) and a few drops of the detergent Tween 20. Segments were washed several times in sterile distilled water until all visible traces of detergent had disappeared. Shoot tips, up to $1.5 \mathrm{~mm}$ diameter and consisting of a meristem and three to five leaf primordia, were dissected from axillary buds and cultured on medium composed of half-strength Murashige and Skoog (1962) salts and vitamins and $1 \mathrm{mg}$ IAA/liter (referred to hereafter as shoot culture medium). The resulting cultures were divided into two-node segments, from which the lower leaf was removed, and maintained on shoot culture medium. These nodal cultures were subculture in this fashion at 4-week intervals unless otherwise indicated.

\section{Leaf culture and adventitious plant development}

Leaves of various sizes were removed from 4-week-old nodal cultures (unless otherwise stated) by a single cut across the petiole that left a $<0.5-\mathrm{mm}$ petiolar stub. Leaf explants were numbered according to phyllotactic position, with the smallest leaf that could be removed intact from a shoot tip with the aid 
of a stereomicroscope being designated as leaf 1. Progressing basipetally, the next leaf was designated leaf 2 , and so on. The lengths of leaves at different positions, taken from a series of experiments with 'French Colombard', are shown in Fig. 1. Leaves from 'Thompson Seedless' nodal cultures were. similar in size to those of 'French Colombard'.

Leaves were cultured on Nitsch and Nitsch (1969) medium with FeEDTA as in Murashige and Skoog (1962) medium and $\mathrm{BAP}$ at $2 \mathrm{mg} \cdot \mathrm{liter}^{-1}$ (referred to hereafter as regeneration medium).

To encourage further development of organogenic tissues and outgrowth of adventitious shoots, intact leaf cultures were transferred to fresh regeneration medium after 4 weeks. In other experiments, regenerating tissues were excised from the explant and transferred to fresh regeneration medium after 4 weeks and again after 8 weeks.

To promote rooting, adventitious shoots were excised and transferred to shoot culture medium after a total of 12 weeks of incubation.

Unless otherwise stated, experiments were repeated at least once and percentage figures represent means with standard errors. For experiments that were not repeated, standard errors were calculated from data for individual experimental units (petri dishes). Commonly, 70 to 80 leaves were cultured in each treatment with seven leaves per petri dish. Details of treatments in individual experiments are presented below.

\section{Results}

\section{Effect of explant and" culture manipulation on shoot organogenesis}

Phyllotactic position (Expt. 1). 'French Colombard' leaves 1 through 6 were cultured for 4 weeks on regeneration medium. Shoot organogenesis decreased substantially with increased leaf maturity (Fig. 1). Regeneration at both lamina and petiole sites was affected similarly, with maximum organogenesis occurring from the smallest leaves.

Age of nodal cultures (Expt. 2). Leaves 1 and 2 from 'Thompson Seedless' nodal cultures 3, 4, 5, and 6 weeks old were cultured on regeneration medium for 4 weeks. Regeneration from leaf 1 was not influenced by nodal culture age (Table 1). In contrast, regeneration from leaf 2 , from both lamina and petiolar sites, was reduced with increasing nodal culture age.

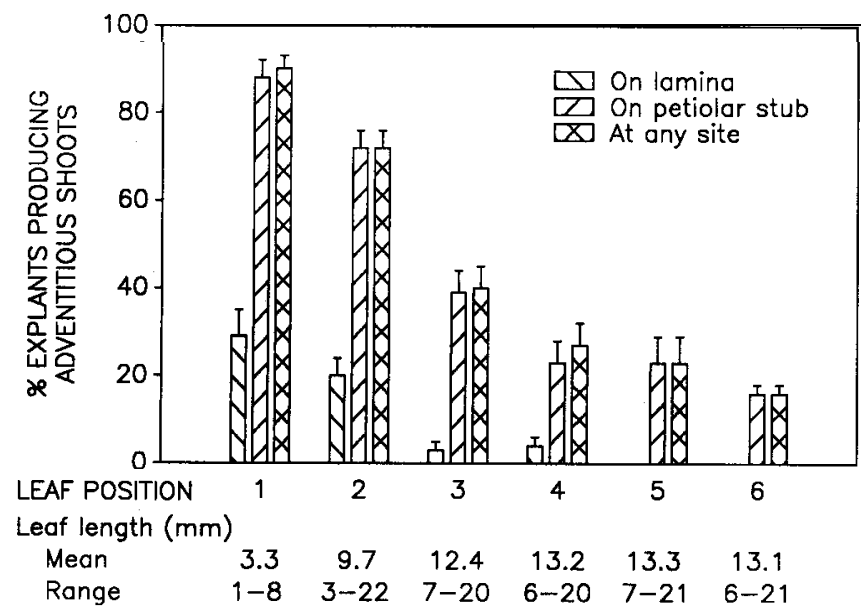

Fig. 1. Effect of leaf position on shoot organogenesis from intact leaves of 'French Colombard'.
Table 1. Effect of nodal culture age on shoot organogenesis from intact leaves of 'Thompson Seedless' excised from nodal cultures and cultured on regeneration medium for 4 weeks.

\begin{tabular}{|c|c|c|c|c|c|}
\hline \multirow{3}{*}{$\begin{array}{l}\text { Leaf } \\
\text { position }\end{array}$} & \multirow{3}{*}{$\begin{array}{c}\text { Site of } \\
\text { regeneration }\end{array}$} & \multicolumn{4}{|c|}{$\begin{array}{l}\text { Explants producing } \\
\text { adventitious shoots }(\%)\end{array}$} \\
\hline & & \multicolumn{4}{|c|}{ Nodal culture age (weeks) ${ }^{z}$} \\
\hline & & 3 & 4 & 5 & 6 \\
\hline 1 & $\begin{array}{l}\text { Petiolar stub } \\
\text { Lamina } \\
\text { Any site }\end{array}$ & $\begin{array}{l}67 \pm 5 \\
16 \pm 5 \\
67 \pm 5\end{array}$ & $\begin{array}{r}67 \pm 5 \\
7 \pm 4 \\
69 \pm 4\end{array}$ & $\begin{array}{l}67 \pm 7 \\
10 \pm 6 \\
69 \pm 6\end{array}$ & $\begin{array}{r}65 \pm 8 \\
8 \pm 3 \\
65 \pm 8\end{array}$ \\
\hline 2 & $\begin{array}{l}\text { Petiolar stub } \\
\text { Lamina } \\
\text { Any site }\end{array}$ & $\begin{array}{l}35 \pm 3 \\
25 \pm 6 \\
43 \pm 5\end{array}$ & $\begin{array}{l}29 \pm 6 \\
16 \pm 6 \\
38 \pm 6\end{array}$ & $\begin{array}{r}20 \pm 3 \\
2 \pm 2 \\
22 \pm 3\end{array}$ & $\begin{array}{l}16 \pm 4 \\
10 \pm 4 \\
20 \pm 3\end{array}$ \\
\hline
\end{tabular}

${ }^{2}$ Cultures were not transferred to fresh medium during this period.

Table 2. Effect of nodal culture transfer on shoot organogenesis from intact leaves of 'French Colombard'.

\begin{tabular}{|c|c|c|c|c|c|}
\hline \multirow{3}{*}{$\begin{array}{l}\text { Leaf } \\
\text { position }\end{array}$} & \multicolumn{5}{|c|}{ Explants producing adventitious shoots (\%) } \\
\hline & \multirow{2}{*}{$\begin{array}{l}\text { Shoot-tip } \\
\text { culture }\end{array}$} & \multicolumn{4}{|c|}{ Nodal culture age (weeks) ${ }^{z}$} \\
\hline & & 4 & 8 & 12 & 20 \\
\hline 1 & $66 \pm 4$ & $54 \pm 6$ & $52 \pm$ & $51 \pm 9$ & $57 \pm 7$ \\
\hline 2 & $70 \pm 8$ & $51 \pm 5$ & $46 \pm 8$ & $57 \pm 5$ & $46 \pm 9$ \\
\hline 3 & $54 \pm 19$ & $18 \pm 5$ & $\operatorname{lo}_{10} \pm$ & $33 \pm 6$ & $16 \pm 4$ \\
\hline 4 & $55 \pm 8$ & $8 \pm 3$ & $\ldots y$ & $21 \pm 8$ & 0 \\
\hline
\end{tabular}

${ }^{2}$ Cultures subculture to fresh medium at $4,8,12$, and 20 weeks. ${ }^{y}$ Data not collected.

Effect of continued nodal culture transfer (Expt. 3). 'French Colombard' leaves 1 through 4 were obtained from 5-week-old shoot-tip cultures before their division into two-node segments for nodal culture. Leaves were also obtained when the resulting nodal cultures were subsequently subculture after $4,8,12$, and 20 weeks. The incidence of shoot organogenesis at lamina and petiolar sites was assessed after 4 weeks on regeneration medium. The experiment was conducted once only. Leaf explants from shoot-tip cultures produced shoots at higher frequencies than did leaves from nodal cultures, but regeneration was not apparently affected by number of nodal culture transfers (Table 2). Shoot-tip culture leaves from different phyllotactic positions responded similarly, as did leaves 1 and 2 from nodal cultures. Regeneration from leaves 3 and 4 taken from nodal cultures at all transfers was significantly lower than that from leaves taken from the initial shoot-tip cultures (Table 2).

Shoot organogenesis from bisected leaves (Expt. 4). 'French Colombard' leaves 1 through 5 were bisected laterally to produce proximal and distal pieces of about equal length. Leaf pieces were placed abaxial surface down on regeneration medium and cultured for 4 weeks. On proximal leaf pieces, shoot organogenesis occurred on the petiolar stub and the lamina surface but not on the cut edge of the lamina (Table 3). On distal pieces, regeneration occurred at up to four sites on the cut edge of the lamina but not on the lamina surface (Table 3). Regeneration from the cut edge of the lamina was usually associated with severed vascular tissue, most commonly the midrib, and was indistinguishable from that occurring at the petiolar stub. In this particular series of experiments, all lamina surface regeneration occurred on explants that also regenerated at their proximal ends.

The incidence of regeneration from distal leaf pieces was always less than that from proximal pieces. As with whole leaves 
Table 3. Shoot organogenesis from bisected leaves of 'French Colombard'.

\begin{tabular}{|c|c|c|c|c|c|}
\hline \multirow[b]{2}{*}{$\begin{array}{l}\text { Leaf } \\
\text { position }\end{array}$} & \multirow[b]{2}{*}{$\begin{array}{l}\text { Leaf } \\
\text { half }\end{array}$} & \multicolumn{4}{|c|}{ Explants producing adventitious shoots (\%) } \\
\hline & & $\begin{array}{c}\text { At proximal } \\
\text { end }\end{array}$ & $\begin{array}{c}>1 \text { site at } \\
\text { proximal } \\
\text { end }\end{array}$ & $\begin{array}{c}\text { On lamina } \\
\text { suface }\end{array}$ & $\begin{array}{l}\text { At any } \\
\text { site } \\
\end{array}$ \\
\hline \multirow[t]{2}{*}{1} & Proximal & $91 \pm 3$ & $\ldots--^{z}$ & $7 \pm 3$ & $91 \pm 3$ \\
\hline & Distal & $67 \pm 6$ & $4 \pm 2$ & 0 & $67 \pm 6$ \\
\hline \multirow[t]{2}{*}{2} & Proximal & $61 \pm 5$ & -- & $5 \pm 3$ & $61 \pm 5$ \\
\hline & Distal & $50 \pm 5$ & $18 \pm 5$ & 0 & $50 \pm 5$ \\
\hline \multirow[t]{2}{*}{3} & Proximal & $12 \pm 4$ & --- & $1 \pm 1$ & $12 \pm 4$ \\
\hline & Distal & $9 \pm 3$ & $1 \pm 1$ & 0 & $9 \pm 3$ \\
\hline \multirow[t]{2}{*}{4} & Proximal & $6 \pm 3$ & --- & 0 & $6 \pm 3$ \\
\hline & Distal & $3 \pm 2$ & 0 & 0 & $3 \pm 2$ \\
\hline \multirow[t]{2}{*}{$J$} & Proximal & $4 \pm 3$ & $\cdots$ & 0 & $4 \pm 3$ \\
\hline & Distal & $3 \pm 3$ & 0 & 0 & $3 \pm 3$ \\
\hline
\end{tabular}

${ }_{2}$ Not applicable to proximal leaf halves since they have only one regeneration site at the proximal end, the petiolar stub.

Table 4. Shoot organogenesis from intact vs. bisected leaves of 'French Colombard'.

\begin{tabular}{|c|c|c|c|c|}
\hline \multirow[b]{2}{*}{ Explant $^{z}$} & \multicolumn{4}{|c|}{ Explants producing adventitious shoots (\%) } \\
\hline & $\begin{array}{c}\text { On petiolar } \\
\text { stub }\end{array}$ & $\begin{array}{l}\text { At proximal } \\
\text { end of distal } \\
\text { half }\end{array}$ & $\begin{array}{c}\text { On lamina } \\
\text { surface }\end{array}$ & $\begin{array}{l}\text { At any } \\
\text { site }\end{array}$ \\
\hline Intact leaf & $43 \pm 5$ & $-y^{\prime}$ & $10 \pm 2$ & $43 \pm 5$ \\
\hline $\begin{array}{l}\text { Bisected leaf } \\
\text { Proximal half } \\
\text { Distal half } \\
\end{array}$ & $\begin{array}{c}58 \pm 7 \\
58 \pm 7 \\
=-\end{array}$ & $\begin{array}{c}54 \pm 6 \\
-- \\
54 \pm 6\end{array}$ & $\begin{array}{l}8 \pm 3 \\
8 \pm 3 \\
4 \pm 2\end{array}$ & $\begin{array}{l}70 \pm 7 \\
58 \pm 7 \\
54 \pm 6\end{array}$ \\
\hline
\end{tabular}

${ }^{z}$ Leaves at positions 2 through 4 combined.

yNot applicable.

(Fig. 1), the regeneration frequency of bisected leaves declined with increasing phyllotactic number (Table 3).

In a second series of experiments with 'French Colombard', leaves 2 through 4 were combined and half of them were bisected as described above. Proximal and distal halves of individual leaves were placed" adjacent to each other so that the response of bisected and intact leaves could be compared. Shoots developed on the lamina surface of intact and bisected leaves at a low incidence and all explants with shoots on the lamina surface also produced shoots at their proximal ends (Table 4). Thirty-four percent of distal explants had more than one regeneration site and several had four sites, usually at the point of severance of vascular tissue (data not shown). There was no apparent difference in regeneration frequencies between proximal and distal leaf halves. When results for the two halves of individual leaves were combined, bisected leaves regenerated at a much higher frequency $(70 \%)$ than did intact leaves $(43 \%)$ (Table 4).

Separation of petiolar stub from lamina (Expt. 5). Petiolar stubs of 'Thompson Seedless' leaves 1 and 2 were separated from the laminae after 1,2, 3, 4, 5, or 6 weeks of incubation on regeneration medium. Stubs and laminae were transferred to fresh regeneration medium at the time of separation and every 4 weeks thereafter for 11 weeks total (preseparation plus postseparation), at which time the frequency of shoot organogenesis from isolated petiolar stubs and from the laminae at the point of removal of the stub was recorded (Table 5). The experiment was conducted only once.

The highest frequency of regeneration was observed from petiolar stubs separated from the lamina at weeks 4 or 5 (Table
Table 5. Effect of separating the petiolar stub from the lamina on shoot organogenesis from leaves of 'Thompson Seedless'.

\begin{tabular}{|c|c|c|c|c|c|c|}
\hline \multirow{3}{*}{$\begin{array}{l}\text { Site of } \\
\text { regeneration }\end{array}$} & \multicolumn{6}{|c|}{ Explants producing adventitious shoots (\%) } \\
\hline & \multicolumn{6}{|c|}{ Week at which petiolar stub removed } \\
\hline & 1 & 2 & 3 & 4 & 5 & 6 \\
\hline Petiolar stub & 0 & $27 \pm 9$ & $44 \pm 12$ & $92 \pm 5$ & $90 \pm 5$ & $81 \pm 6$ \\
\hline $\begin{array}{l}\text { Proximal end } \\
\text { of lamina }^{z}\end{array}$ & 0 & $15 \pm 7$ & $9 \pm 8$ & $31 \pm 10$ & $26 \pm 9$ & $6 \pm 6$ \\
\hline
\end{tabular}

${ }^{2}$ After stub removal.

5). Significantly inferior responses resulted from earlier separation and those stubs separated at week 6 also showed somewhat reduced regeneration. Shoots developed at the wounded proximal. end of the leaf lamina when petiolar stubs were removed at weeks 2 through 6, with a maximum occurring when petiolar stubs were removed at week 4 (Table 5). Shoot organogenesis from these tissues appeared identical to that at the petiolar stub but resulted in smaller regions of adventitious growth with fewer shoots

\section{Effect of explant and culture manipulation on shoot outgrowth}

Isolation of organogenic tissues from intact leaves (Expt. 6). 'French Colombard' leaves 1 and 2 were cultured for 4 weeks, after which time nonregenerating cultures were discarded and the remainder were divided into two groups. Regenerating petiolar stubs were isolated from one group while explants in the other group were left intact. Regenerating tissues on lamina surfaces were isolated from both groups by careful excision at their point of attachment to the leaf. The cultures were incubated for an additional 4 weeks on fresh regeneration medium before assessment of results at week 8 and transfer again to fresh medium. Isolation of regenerating petiolar tissues resulted in superior shoot outgrowth compared to intact leaf cultures (Table $6)$. Best development occurred from petiolar stub cultures isolated from leaf $1,83 \%$ of which had shoots $>3 \mathrm{~mm}$ long. The frequency of shoot outgrowth was poor from lamina surface regeneration sites. A relatively high proportion of these tissues died when isolated from the lamina.

Similar numbers of shoots developed from all culture types. Shoots from the various treatments looked similar and ranged in length from 5 to $15 \mathrm{~mm}$ with three to seven nodes. Shoot number and size increased with further incubation (data not shown). Some lamina browning and necrosis were observed during the second 4 weeks.

Isolation of organogenic tissues from bisected leaves (Expt. 7). 'French Colombard' leaves 1 and 2 were bisected into proximal and distal halves and cultured for 4 weeks, after which time regenerating cultures were separated into two groups and half were transferred intact to fresh regeneration medium. In the other cultures, regenerating tissues from both petiolar stubs and cut lamina edges (but not from the lamina surface) were isolated from the original explants and also transferred to fresh medium. Cultures were transferred again to fresh medium after an additional 4 weeks and results were assessed at week 12. As with intact leaf explants, superior shoot outgrowth was promoted by separation of the organogenic tissues from the remainder of the leaf. Shoot numbers and the incidence of shoot outgrowth were similar for both proximal and distal leaf halves (Table 7). Shoots from all treatments were similar in appearance and were up to $20 \mathrm{~mm}$ long with fewer than seven nodes. 
Table 6. Shoot outgrowth from organogenic sites on 'French Colombard' leaves after 8 weeks.

\begin{tabular}{|c|c|c|c|}
\hline $\begin{array}{l}\text { Leaf } \\
\text { positior }\end{array}$ & $\begin{array}{llll}\mathrm{S} & \mathrm{i} & \mathrm{t} & \mathrm{e} \\
\end{array}$ & $\begin{array}{c}\text { Explants } \\
\text { with shoots } \\
>3 \quad \text { mmlong }(\%) \\
\end{array}$ & $\begin{array}{l}\text { Mean no. } \\
\text { shoots }>3 \mathrm{~mm} / \\
\text { explant } \\
\end{array}$ \\
\hline $\begin{array}{l}\text { P } \\
\text { Is } \\
\text { Is }\end{array}$ & $\begin{array}{l}\text { Petiolar stub on intact leaf } \\
\text { Isolated petiolar stub } \\
\text { Isolated lamina site }\end{array}$ & $\begin{array}{l}56 \pm 4 \\
83 \pm 9 \\
13 \pm 5\end{array}$ & $\begin{array}{l}4.6 \pm 0.7 \\
3.7 \pm 0.5 \\
4.7 \pm 1.3\end{array}$ \\
\hline $\begin{array}{l}\text { P } \\
\text { Is } \\
\text { Is }\end{array}$ & $\begin{array}{l}\text { Petiolar stub on intact leaf } \\
\text { [solated petiolar stub } \\
\text { [solated lamina site }\end{array}$ & $\begin{array}{l}38 \pm 7 \\
52 \pm 6 \\
24 \pm 4\end{array}$ & $\begin{array}{l}3.1 \pm 0.7 \\
6.8 \pm 0.8 \\
4.3 \pm 1.2\end{array}$ \\
\hline
\end{tabular}

־Isolated after 4 weeks.

Table7. Shoot outgrowth from organogenic sites on bisected leaves of 'French Colombard' after 12 weeks.

\begin{tabular}{|c|c|c|c|c|}
\hline $\begin{array}{l}\text { Leaf } \\
\text { position }\end{array}$ & $\begin{array}{l}\text { Leaf } \\
\text { half }\end{array}$ & & $\begin{array}{c}\text { Explants } \\
\text { with shoots } \\
>3 \mathrm{~mm} \text { long } \\
(\%)\end{array}$ & $\begin{array}{l}\text { Mean no. } \\
\text { shoots >3 mm/ } \\
\text { explant }\end{array}$ \\
\hline \multirow[t]{2}{*}{1} & Proximal & $\begin{array}{l}\text { Intact explant } \\
\text { Isolated site }\end{array}$ & $\begin{array}{l}49 \pm 8 \\
69 \pm 11\end{array}$ & $\begin{array}{l}3.7 \pm 0.4 \\
3.4 \pm 0.3\end{array}$ \\
\hline & Distal & $\begin{array}{l}\text { Intact explant } \\
\text { Isolated site }\end{array}$ & $\begin{array}{l}20 \pm 6 \\
43 \pm 16\end{array}$ & $\begin{array}{l}2.7 \pm 0.4 \\
4.1 \pm 0.4\end{array}$ \\
\hline \multirow[t]{2}{*}{2} & Proximal & $\begin{array}{l}\text { Intact explant } \\
\text { Isolated site }\end{array}$ & $\begin{array}{l}54 \pm 18 \\
66 \pm 13\end{array}$ & $\begin{array}{l}2.7 \pm 0.5 \\
3.6 \pm 0.6\end{array}$ \\
\hline & Distal & $\begin{array}{l}\text { Intact explant } \\
\text { Isolated site }\end{array}$ & $\begin{array}{l}45 \pm 10 \\
75 \pm 11\end{array}$ & $\begin{array}{l}5.5 \pm 0.9 \\
4.3 \pm 0.4\end{array}$ \\
\hline
\end{tabular}

'Isolated after 4 weeks. Only sites at petiolar stub of proximal halves and cut edge of distal halves; no lamina surface sites isolated.

\section{Plant development from adventitious shoots}

Adventitious shoots 5 to $20 \mathrm{~mm}$ long were removed at week 12 from the petiolar stub, intact leaf, and lamina cultures noted in Expt. 6 above. Cultures derived from various leaf positions were mixed before shoot isolation. Shoots were transferred to shoot culture medium and results were assessed after an additional 4 weeks. Root initials developed from the base of the shoots within the first 2 weeks, $74 \% \pm 6 \%$ for shoots from isolated petiolar stubs, $76 \% \pm 8 \%$ for shoots from petiolar stubs on intact leaves, and $62 \% \pm 3 \%$ on shoots from isolated lamina sites. Further shoot growth occurred only from rooted shoots. Plants appeared morphologically identical to shoot-tip and nodal cultures. Preliminary cytological examination of root tip squashes indicated that regenerated plants were diploid $(2 \mathrm{n}=38)$ (data not shown).

\section{Discussion}

The youngest leaves were the most organogenic at all regeneration sites. These results were not unexpected since such correlations between explant maturity and morphogenic competence have been observed previously in both shoot organogenic ( $\mathrm{Fa}-$ solo et al., 1989; Mroginski and Kartha, 1981; Mroginski et al., 1981; Omura et al., 1987; Welander, 1988) and embryogenic systems (Dale, 1980; Hakman et al., 1985; Stamp and Henshaw, 1987; Wernicke and Brettell, 1980). Tissue immaturity is known to be related to morphogenic competence and differentiation in plants is associated with loss of "regenerative capacity" (Sinnott, 1960). Consequently, tissues developmentally close to apical meristems are more likely to be morphogenically competent. Shoot apices of grape have been previously shown to be organogenically competent (Barlass and
Skene, 1978, 1980b); adventitious shoots develop at the basal ends of leaf primordium fragments through. a developmental process apparently very similar to that observed for intact leaf explants (S.M. Colby, A.M. Juncosa, J.A. Stamp, and C.P. Meredith, unpublished results).

The physiological status of the donor shoot affected subsequent adventitious regeneration from leaf explants. Regeneration declined with increasing nodal culture age, but only if the nodal cultures were not transferred to fresh medium (Table 1). If they were transferred to fresh medium at regular intervals, regeneration did not decline, even from nodal cultures that were 20 weeks old (Table 2), suggesting that the decline associated with leaf explants from untransferred cultures may reflect nutrient depletion or the accumulation of inhibitory substances in the medium. Leaf 1 was unaffected by culture age (Table 1), perhaps because it was a stronger sink for nutrients or because it was less affected by inhibitors in the medium.

Leaf explants taken from newly established shoot-tip cultures produced shoots at a consistently higher frequency than those from nodal cultures, and the frequency did not decline with leaf position (Table 2). This phenomenon may reflect a qualitative physiological difference between shoot-tip cultures and nodal cultures and is probably not due simply to time in culture, since time had no effect in regularly transferred nodal cultures. Preliminary experiments have suggested that leaves isolated directly from greenhouse-grown plants regenerate at a higher frequency than those from nodal cultures (J.A. Stamp, A.P. Conry-Whittlesey, and C.P. Meredith, unpublished results). The physiological state of shoot-tip cultures may represent an intermediate state between soil-grown plants and those maintained in culture.

In bisected leaves, regeneration occurred almost exclusively from proximal edges at the site of vascular wounding, whether at the petiolar stub or the cut lamina. Such polarized regeneration has been observed in other shoot organogenic systems (Fasolo et al., 1989; Kouider et al., 1984; Mroginski et al., 1981; Welander, 1988) and embryogenic systems (Stamp, 1987; Wernicke and Brettell, 1980), with maximum regeneration commonly occurring from proximal tissues. In grape, however, as in pear (Chevreau et al., 1989), the frequency of regeneration from proximal vs. distal leaf halves was similar, except for leaf 1 (Tables 3, 4), and a comparison of intact and bisected leaves (Table 4) shows that bisection increased the percentage of leaves that produced adventitious shoots (70\% vs. $43 \%)$. The greater number of potential regeneration sites in bisected leaves (i.e., severed veins on distal explants) most likely accounts for this difference. The greater number of potential regeneration sites produced by leaf bisection may prove important for Agrobacterium-mediated transformation of grape in which the coirrci- 
dence of Agrobacterium-injectable wounds and tissues capable of regeneration is of critical importance. Additional cuts across the midrib, as examined in apple (Fasolo et al., 1989), might result in an increased number of regeneration sites per leaf.

Separating the petiolar stub from the lamina during" the first 3 weeks of culture reduced the frequency of regeneration considerably (Table 5). Previous studies (Stamp et al., 1990) had shown that transfer of intact leaves to fresh regeneration medium after 1,2 , or 4 weeks had no effect on regeneration, suggesting that the results observed here are a consequence of petiolar isolation" rather than transfer to fresh medium. The leaf tissues remaining after the removal of the petiolar stub also produced shoots at their cut proximal end in some cases (Table 5). This "supplementary" regeneration indicates that some leaves remain morphogenically competent after 5 or 6 weeks of incubation and that expression of this competence is stimulated by wounding and transfer to fresh regeneration medium.

The isolation of proximal regeneration sites promoted shoot outgrowth from both entire and bisected leaves (Tables 6, 7), demonstrating that the leaf lamina can inhibit the elongation of adventitious shoots. It may compete with the petiolar stub for nutrients or hinder the movement of growth regulators or be a source of inhibitory compounds. The latter possibility is supported by the observation of lamina browning and necrosis during the second 4 weeks.

Nodal cultures maintained in vitro are a reliable means for the production of leaf explants suitable for the routine production of adventitious shoots. Careful selection of explants and subsequent explant manipulation can significantly enhance the organogenic response.

\section{Literature Cited}

Barlass, M. and K.G.M. Skene. 1978. In vitro propagation of grapevine Vitis vinifera (L.) from fragmented shoot apices. Vitis 17:335340.

Barlass, M. and K.G.M. Skene. 1980a. Studies on the fragmented shoot apex of grapevine. I. The regenerative capacity of leaf primordial fragments in vitro. J. Expt. Bot, 31:483-488.

Barlass, M. and K.G.M. Skene. 1980b. Studies on the fragmented shoot apex of grapevine. II. Factors affecting growth and differentiation in vitro. J. Expt. Bet. 31:489-495.

Bouquet, A., B. Piganeau, and A.-M. Lamaison. 1982. Influence du genotype sur la production de cals, d'embryoides et de plantes entieres par culture d'antheres in vitro clans le genre Vitis. Compt. Rend. Acad. Sci. Paris 295:569-574.

California Agricultural Statistics Service. 1989. California grape acreage 1988. California Dept. Food and Agr., Sacramento.

Chevreau, E., R.M. Skirvin, H.A. Abu-Qaoud, S.S. Korban, and J.G. Sullivan. 1989. Adventitious shoot regeneration from leaf tissue of three pear (Pyrus sp.) cultivars in vitro. Plant Cell Rpt. 7:688-691.

Dale, P.J. 1980. Embryoids from cultured immature embryos of $\mathrm{Lol}$ ium multiflorum. Z. Pflanzenphysiol. 100:73-77.

Fasolo, F., R.H. Zimmerman, and I. Fordham. 1989. Adventitious shoot formation on excised leaves of in vitro grown shoots of apple cultivars. Plant Cell Tissue Organ Culture 16:75-87.

Favre, J.-M. 1977. Premiers resultats concernant l'obtention in vitro de neoformations caulinaires chez la Vigne. Ann. Amélior. Plantes 27:151-169.

Gray, D.J. and J.A. Mortensen. 1987. Initiation and maintenance of long term somatic embryogenesis from anthers and ovaries of Vitis longii 'Microsperma'. Plant Cell Tissue Organ Culture 9:73-80.

Hakman, I., L.C. Fowke, S. von Arnold, and T. Erickson. 1985. The development of somatic embryos in tissue cultures initiated from immature embryos of Picea abies (Norway Spruce). Plant Sci. 38:5359.

Hirabayashi, T. 1985. Somatic embryogenesis from leaf tissues of grape. Colloque Amelioration de la Vigne et Culture In Vitro, 2324 Apr., Paris. p. 75-82.

Kouider, M., S.S. Korban, R.M. Skirvin, and M.C. Chu. 1984. Influence of embryonic dominance and polarity on adventitious shoot formation from apple cotyledons in vitro. J. Amer. Soc. Hort. Sci. 109:381-385.

Krul, W.R. and J.F. Worley. 1977. Formation of adventitious embryos in callus cultures of 'Seyval', a French hybrid grape. J. Amer. Soc. Hort. Sci. 102:360-363.

Mauro, M.Cl., C. Nef, and J. Fallot. 1986. Stimulation of somatic embryogenesis and plant regeneration from anther culture of Vitis vinifera cv. Cabernet Sauvignon. Plant Cell Rpt. $5: 377-380$.

Monette, P.L. 1988. Grapevine (Vitis vinifera L.), p. 3-37. In: Y.P.S. Bajaj (cd.). Biotechnology in agriculture and forestry. vol. 6. Crops H. Springer-Verlag, Berlin.

Mroginski, L.A. and K.K. Kartha. 1981. Regeneration of pea (Pisum sativum L. cv. Century) plants by in vitro culture of immature leaflets. Plant Cell Rpt. 1:64-66.

Mroginski, L. A., K.K. Kartha, and J.P. Shyluk. 1981. Regeneration of peanut (Arachis hypogaea) plant lets by in vitro culture of immature leaves. Can. J. Bet. 59:826-830.

Mullins, M.G. and C. Srinivasan. 1976. Somatic embryos and plantlets from an ancient clone of the grapevine (cv. Cabernet Sauvignon) by apomixis in vitro. J. Expt. Bet. 27:1022-1030.

Murashige, T. and F. Skoog. 1962. A revised medium for rapid growth and bioassays with tobacco tissue cultures. Physiologic Plantarum 15:473-497.

Nitsch, J.P. and C. Nitsch. 1969. Haploid plants from pollen grains. Science 163:85-87.

Omura, M., N. Matsuta, T. Moriguchi, I, Kozaki, and T. Sanada. 1987. Establishment of tissue culture methods in dwarf pomegranate (Punica granatum L. var. nana) and application for the induction of variants. Jpn. Min. Agr., For. and Fisheries, Bul. Fruit Tree Res. Sta. A 14:17-44.

Rajasekaran, K. and M.G. Mullins. 1979. Embryos and plantlets from cultured anthers of hybrid grapevines. J. Expt. Bet. 30:399-407.

Rajasekaran, K. and M.G. Mullins. 1981. Organogenesis in internode explants of grapevines. Vitis 20:218-227.

Rajasekaran, K. and M.G. Mullins. 1983. The origin of embryos and plantlets from cultured anthers of hybrid grapevines. Amer. J. Enol. Vitic. 34:108-113.

Sinnott, E.W. 1960. Plant morphogenesis. McGraw-Hill, New York. Srinivasan, C. and M.G. Mullins. 1980, High-frequency somatic embryo production from unfertilized ovules of grapes. Scientia Hort. 13:245-252.

Stamp, J.A. 1987. Somatic embryogenesis in cassava: the anatomy and morphology of the regeneration process. Ann, Bot. 59:45 1-459.

Stamp, J. A., S.M. Colby, and C.P. Meredith. 1990. Direct shoot organogenesis and plant regeneration from leaves of grape (Vitis vinifera L.) Plant Cell Tissue Organ Culture 22: 127-133.

Stamp, J.A. and G.G. Henshaw. 1987. Somatic embryogenesis from clonal leaf tissues of cassava. Ann. Bot. 59:445-450.

Stamp, J.A. and C.P. Meredith. 1988a. Somatic embryogenesis from leaves and anthers of grapevine. Scientia Hort. 35:235-250.

Stamp, J.A. and C.P. Meredith. 1988b. Proliferative somatic embryogenesis from zygotic embryos of grapevine. J. Amer. Soc. Hort. Sci. 113:941-945.

Welander, M. 1988. Plant regeneration from leaf and stem segments of shoots raised in vitro from mature apple trees. J. Plant Physiol. 132:738-744.

Wernicke, W. and R. Brettell. 1980. Somatic embryogenesis from Sorghum bicolor leaves. Nature (London) 287:138-139, 